\title{
Effect of Modeling Beam-Column Joints on Performance Assessment of Columns in Non-Ductile RC Frames
}

\author{
Sadık Can GÍRGíN ${ }^{1}$
}

\begin{abstract}
Seismic performance evaluation of non-seismically detailed reinforced concrete (RC) buildings requires proper analytical modeling approaches for beam-column joints which are most vulnerable parts. This study investigates the influence of beam column joint modeling assumptions on performance evaluation of non-ductile RC buildings. Numerical simulation model includes truss-based elements for beam-column connections and fiber-based elements for beams and columns. Two-dimensional four- and six- story reinforced concrete frames of an existing $\mathrm{RC}$ building are designed and analyzed by conducting incremental dynamic analyses. Column chord rotations and corresponding strains are compared with code provisions for performance assessment of non-ductile RC frames.
\end{abstract}

Keywords: Beam-column joints, non-ductile frames, hybrid model, performance limits.

\section{INTRODUCTION}

Beam-column joints in reinforced concrete $(\mathrm{RC})$ buildings are expected to transfer flexure and shear forces without significant strength and stiffness degradation in modern construction practice. However, older-type RC buildings constitute a significant portion of the building inventory designed only considering gravity loads before 1970's in earthquake-prone regions (Figure 1a). Field observations after earthquakes revealed that brittle failure modes may occur at the vicinity of beam-column joints in reinforced concrete frames those nonconforming the design requirements. Observed failure modes in $\mathrm{RC}$ beam-column joints are reported due to non-seismic detailing such as insufficient anchorage of beam rebars, lack of transverse reinforcement in the joint and discontinuity of beam and column rebars (Figure 1b). There has been a significant amount of experimental research on cyclic behavior of exterior beam- column joints with respect to axial load ratio, transverse reinforcement ratio, anchorage detailing of beam rebars and drift histories [1-5]. Bedirhanoğlu et al. (2010) [6] tested exterior beam-column joints representing construction practice deficiencies in Turkey before 1970's. Main test variables were the effect of displacement history, axial load, presence of transverse beam in the joint and amount of joint reinforcement. They concluded

\section{Note:}

- This paper has been received on September 3, 2018 and accepted for publication by the Editorial Board on May 30, 2019.

- Discussions on this paper will be accepted by January 31, 2021.

- https://dx.doi.org/10.18400/tekderg.456752

1 Dokuz Eylul University, Department of Civil Engineering, İzmir, Turkey - sadik.girgin@deu.edu.tr https://orcid.org/0000-0002-5224-3122 
that presence of lateral beam didn't have significant effect on bond of reinforcing bars in the joint. Gökdemir and Tankut (2017) [7] tested 4 reference and 7 strengthened exterior beamcolumn joints with diagonal steel bars. Reference specimen without shear reinforcement showed significant strength degradation at small drifts. On the other hand, for interior beamcolumn joints without transverse reinforcement, significant stiffness degradation will occur due to insufficient development length of beam longitudinal bars [8]. Interior beam-column joint specimens were tested by Alire (2002), and damages were observed with a combination of bond-slip of reinforcing bars and shear cracks in the joint [9].

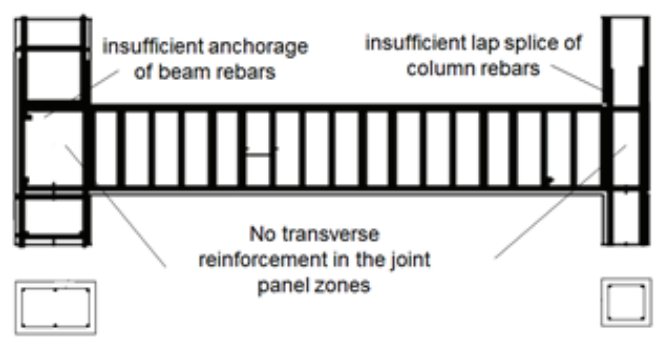

(a)

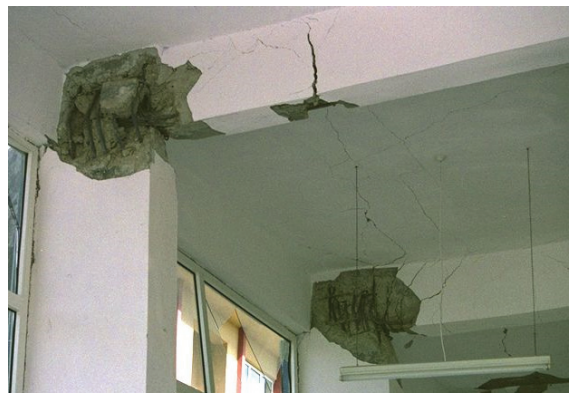

(b)

Figure 1 - (a) Typical detailing of beam-column connections built before 1970's, (b) Damage to beam-column joint from August 17, 1999 Kocaeli Earthquake (nisee.berkeley.edu)

Although beam-column joints characterize the seismic behavior of existing RC buildings, rigid joint assumption is generally considered in design-oriented analyses [10]. Analytical models ignoring joint flexibility using rigid joint assumption may lead to underestimation in damage levels of RC members [11]. Hence, seismic performance assessment of existing RC buildings requires refined analytical tools accounting for damage states of non- seismically detailed beam-column joints. Modeling approaches for numerical simulation of beamcolumn joints can be classified as (i) lumped plasticity models, (ii) distributed plasticity (fiber-based) models, and (iii) truss-based models. Lumped plasticity models are employed to simulate nonlinear behavior of structural elements with concentrated nonlinearities in a finite length. Zero-length rotational springs or moment-curvature relations within a specified length, which follow nonlinear hysteretic rules, can be assigned to the ends of beam-column elements [12-15]. These models also include springs representing shear, bond slip and rigid links at the vicinity of the connection [11, 15-18]. Distributed plasticity models with fiberbased beam-column elements provide sufficient estimation for local response parameters such as curvature and strains. Element cross section is discretized into fibers at integration points along the element length. Force-based formulation for nonlinear beam-column elements has advantages over the displacement-based formulation, because equilibrium is satisfied at each section and end node for force interpolation function [19].

Truss-based modeling approaches have been studied for design and analysis of RC members subjected to shear, flexure and axial forces [20-23]. Panagiotou et al. (2012) [24] improved 
existing truss modeling approaches by including mesh size effects and biaxial effects for diagonal elements in compression. Moharrami et al. (2015) [25] enhanced the truss model for analysis of shear-critical RC columns including the contribution of aggregate interlock effects. Bowers (2014) [26] and Xing et al. (2018) [27] proposed a hybrid numerical model for beam-column joints of non-ductile frames including nonlinear cyclic truss model for connection region and distributed plasticity model for beams and columns.

This study investigates the influence of beam column joint modeling assumptions on performance evaluation of non-ductile RC frames. For this purpose, a hybrid analytical model is validated by using test results of exterior beam-column joint specimens representing joints in existing buildings. Two-dimensional structural models of four- and six- story buildings were modeled using the hybrid model and analyzed by incremental dynamic analyses. Rotation-based and strain-based performance limits of RC members are investigated and compared with the code provisions.

\section{NUMERICAL SIMULATION OF BEAM-COLUMN JOINTS}

\subsection{Numerical Simulation Model}

In this study, all numerical analyses are performed by using OpenSees computer program [28]. Bowers (2014) [26] proposed a numerical simulation model for shear critical interior and exterior beam-column joints and validated cyclic behavior of joint tests representing existing buildings. The numerical model includes nonlinear cyclic truss model for connection region and distributed plasticity model for beams and columns as shown in Figure 2. Nonlinear truss model is established by assignment of location of horizontal elements including longitudinal rebars for beams and diagonal element angles. Truss model herein uses elements in the horizontal, vertical and diagonal directions representing steel reinforcement and concrete areas. Nonlinear concrete trusses for diagonal elements account for biaxial effects on the compression behavior while tension stiffening effects are considered in the vertical and horizontal directions. Nonlinear force-based beam-column elements with Gauss-Lobatto quadrature and two integration points with linear transformation are used for beams and columns.

\subsection{Material Models}

Giuffré-Menegotto-Pinto (GMP) steel material model is used to define the stress-strain relationship for the reinforcing steel. A GMP model is shown in Figure 3, where $f_{\mathrm{y}}$ is the yield strength, the corresponding yield strain $\varepsilon_{\mathrm{y}}, \mathrm{E}_{\mathrm{s}}$ the elastic modulus, and $\mathrm{B}_{\mathrm{s}}$ the post-yield hardening ratio - the monotonic envelope for this material model is bilinear.

The stress-strain law for concrete proposed by Lu and Panagiotou (2014) [29] which is schematically presented in Figure 4 where $\mathrm{f}_{\mathrm{c}}$ ' is the compressive strength at $\varepsilon_{0}=0.2 \%$ strain for unconfined concrete. Ultimate strain $\left(\mathcal{E}_{\mathrm{u}}\right)$ of concrete is adjusted by accounting for the mesh-size effects due to the procedure outlined by $\mathrm{Lu}$ and Panagiotou (2014) [29]. For horizontal and vertical concrete truss elements, tensile strength is $f_{t}=0.33 \sqrt{f_{c k}}(\mathrm{MPa})$ with a softening portion in accordance with tension stiffening by Stevens et al. (1991) [30]: 


$$
\begin{aligned}
& f=f_{t}\left[(1-M) e^{-\lambda_{t}\left(\varepsilon-\varepsilon_{c r}\right)}+M\right] \\
& M=C_{t} \frac{\rho_{l}}{d_{b}} \\
& \lambda_{t}=\frac{540}{\sqrt{M}}
\end{aligned}
$$

where $\rho_{1}$ is steel ratio in the horizontal and vertical truss elements, $M$ is tension stiffening parameter, $d_{b}$ is rebar diameter and $C_{t}=75 \mathrm{~mm}$.

The concrete material model for the diagonal elements considers for the reduction of compressive strength due to transverse strains described by Vecchio and Collins (1986) [31]. Compressive stresses are multiplied by a reduction coefficient $(\beta)$ at each analysis step based on calculated transverse strains using fictitious strain gauge elements. Figure 5 shows the relation between stress reduction factor, $\beta$, and normal strain, $\varepsilon_{\mathrm{n}}$. The values of $\beta_{\text {int }}=0.3$ and $\beta_{\text {res }}=0.1$ are considered for the analyses.

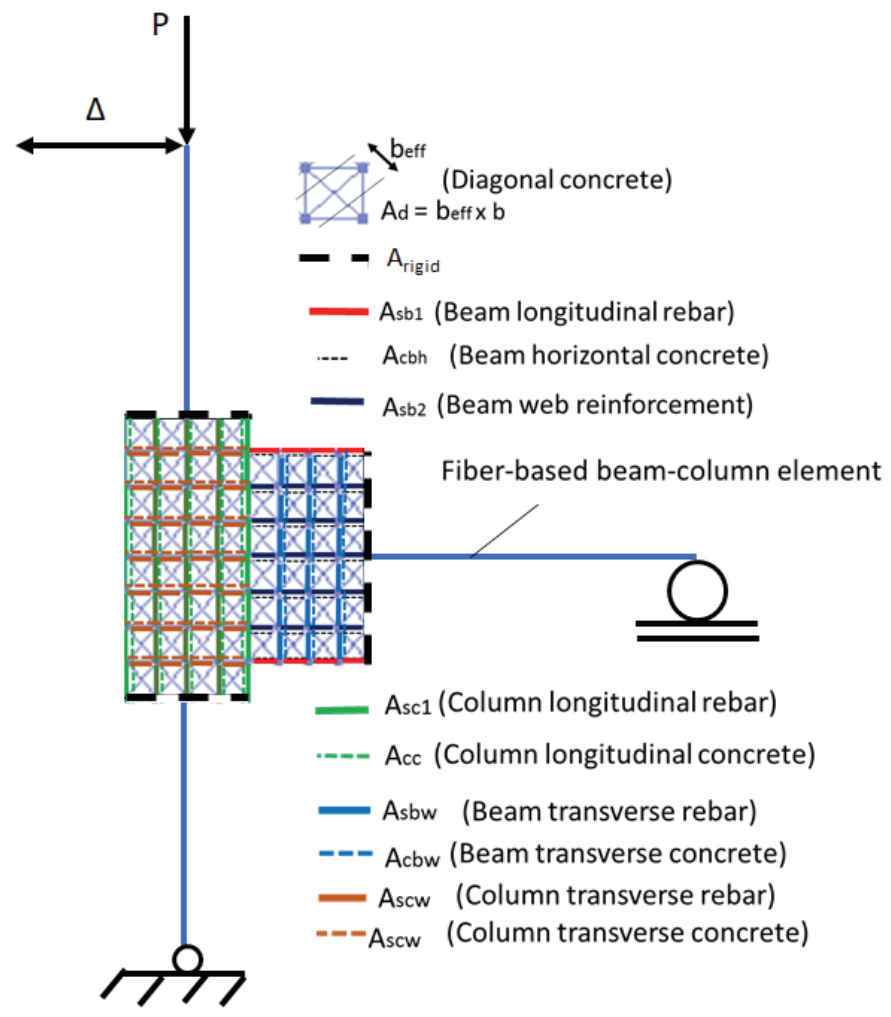

Figure 2 - Numerical simulation model for an exterior beam-column joint 


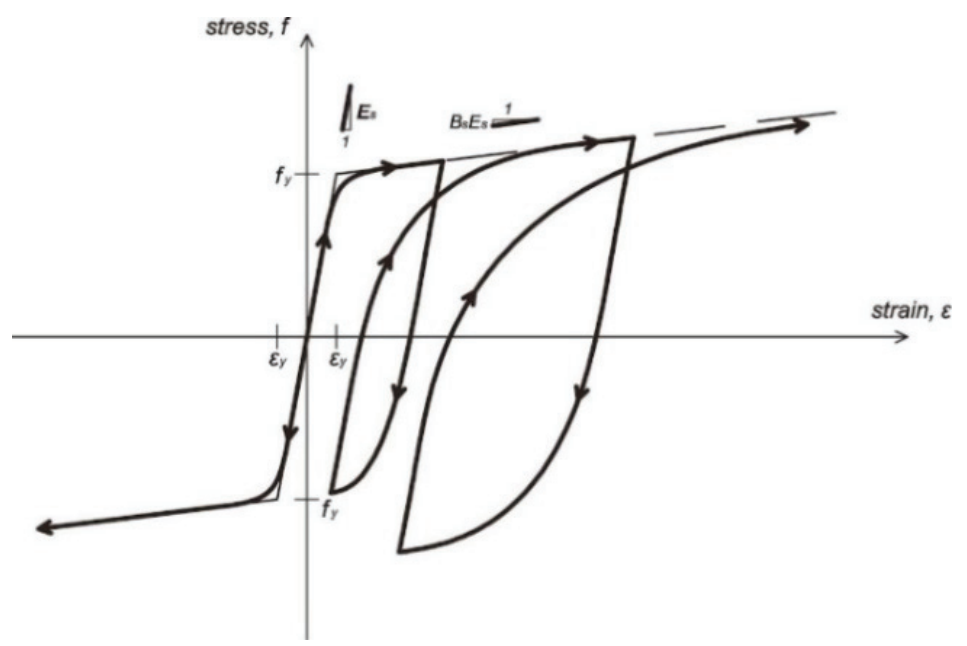

Figure 3 - Stress-strain relationship of the GMP steel material model

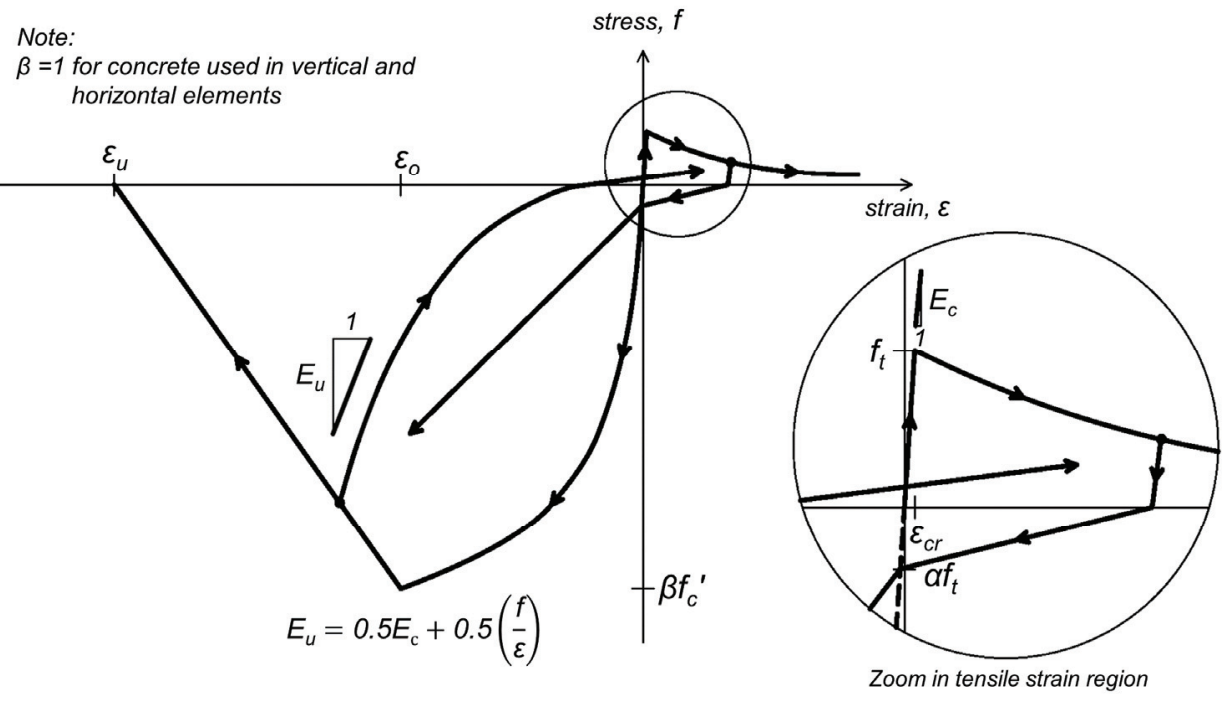

Figure 4 - Stress-strain relationship of concrete material models [29]. 


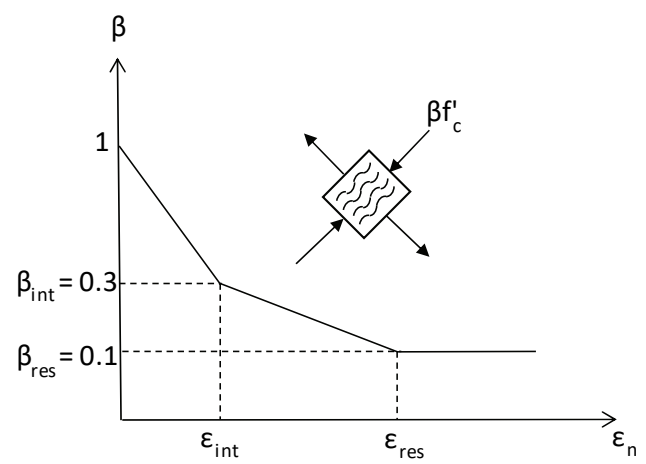

Figure 5 - Relation between reduction factor and normal strain

\section{CASE STUDIES}

Experimental research studies on non-seismically detailed beam-column joints conducted by Misir and Kahraman (2013) [32] and Pantelides et al. (2002) [33] are considered in this study. Geometry and reinforcing details of 2/3 scale S1 specimen [32] and full-scale Unit 4 [33] are shown in Figure 6. One reference (S1) and two exterior beam-column joints strengthened with SIFCON blocks were tested by Misir and Kahraman (2013) [32]. For S1 specimen, average concrete strength was $10 \mathrm{MPa}$ for beam-column joint at the test day. Beam and column longitudinal rebars with 8- and 10-mm diameters had $402 \mathrm{MPa}$ and $411 \mathrm{MPa}$ yield strengths, respectively. Axial load was applied under $15 \%$ of column axial load capacity during cyclic reversals. Lateral cyclic displacements were applied at the top of the column with increasing amplitude from $0.15 \%$ to $3.5 \%$ drift ratios. During the test, first flexural and diagonal cracks were observed at $0.15 \%$ and $0.75 \%$ drift ratios, respectively. Shear cracks increased and expanded in the joint panel at $1 \%$ drift ratio. At $1.75 \%$ drift ratio, concrete cone developed, detached from the specimen and severe pinching was observed following $0.75 \%$ drift ratio due to shear deformations. Lateral strength of the specimen was reached at $0.5 \%$ drift ratio and test was continued up to third the cycle of $3.5 \%$ drift ratio at which specimen showed heavily damage state.

Figure 7 shows the hybrid models with different mesh sizes as Model-A and Model-B for beam-column joint specimen (S1). Nonlinear concrete trusses in the vertical and horizontal directions account for tension stiffening effects. Inclination angle of diagonal elements with respect to horizontal axis is considered as $46^{\circ}$. Nonlinear truss model is connected to forcebased beam-column elements with rigid elements as shown in Figures 7 (a) and (b). The lateral force- displacement responses for experimentally measured and cyclically computed using numerical simulation model are compared in Figure 8 (a) and (b). Both models computed stiffness degradation as well as pinching in a good agreement with cyclic behavior of specimen (Figure 8c) and the failure mode is captured with the diagonal concrete crushing. 




(a)

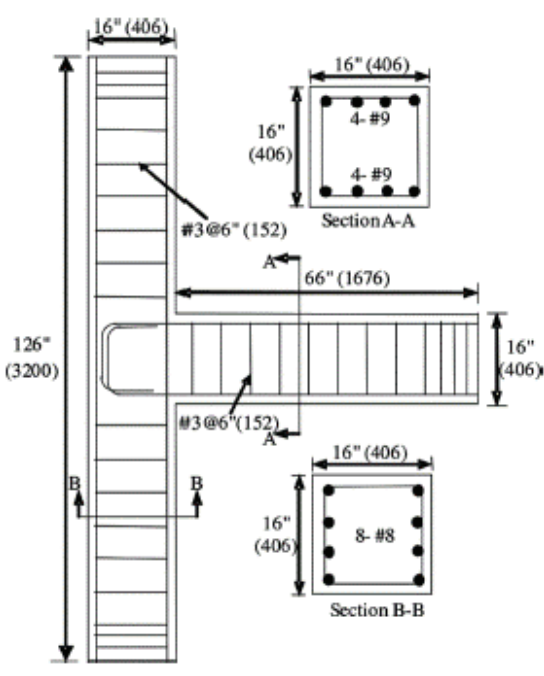

(b)

Figure 6 - Geometry and reinforcing details of unreinforced beam-column joint for (a) S1 specimen tested by Misir and Kahraman [32], and (b) Unit 4 tested by Pantelides et al. [33]

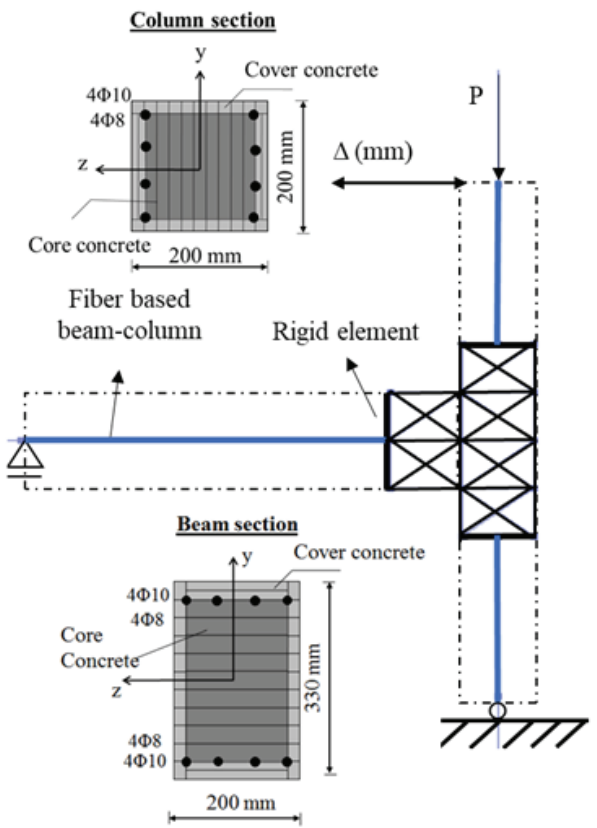

(a)

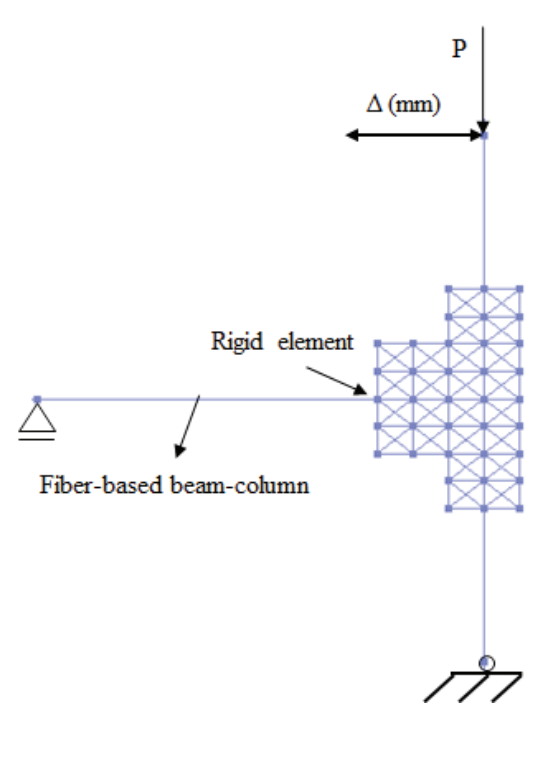

(b)

Figure 7 - Numerical simulation models for S1 specimen (a)Model A and (b) Model B 


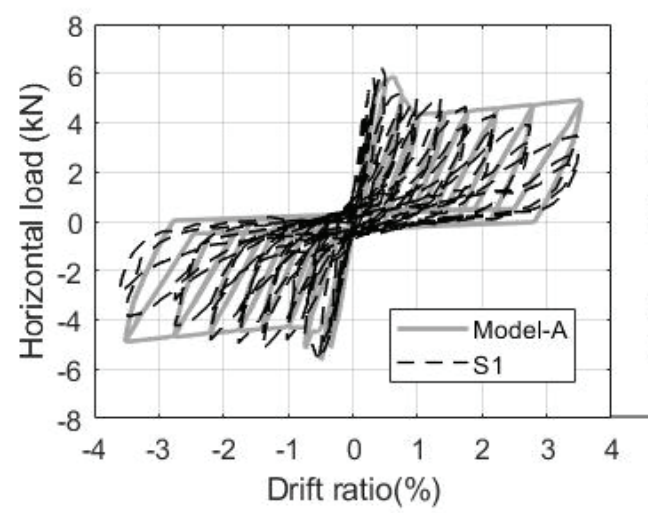

(a)

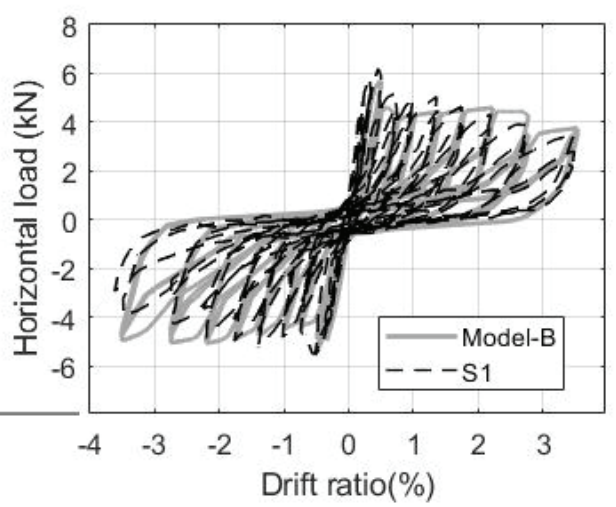

(b)

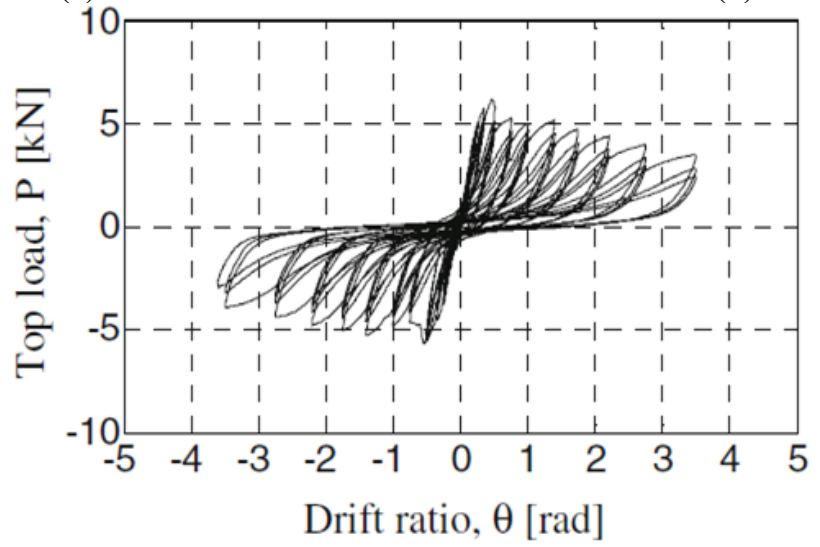

(c)

Figure 8 - Comparison of measured and computed responses for S1 specimen and (a) Model$A$, and (b) Model-B and (c) lateral load-drift ratio relationships for S1 specimen [32]

Pantelides et al. (2002) [33] tested six exterior full-scale beam-column joints with different details of beam reinforcement and axial load ratios. For Unit-4 specimen shown in Figure 6b, average concrete strength was $31.6 \mathrm{MPa}$ at the test day and beam and column longitudinal rebars with 25- and 29-mm diameters had $469 \mathrm{MPa}$ and $458.5 \mathrm{MPa}$ yield strengths, respectively. Axial load was applied under $25 \%$ of column axial load capacity during cyclic reversals. During the test, first yield in longitudinal reinforcement was observed and initial significant cracking in the joint was observed at at $0.5 \%$ and $1.5 \%$ drift ratios, respectively. Shear cracks increased and expanded in the joint panel at $2 \%$ drift ratio. At $5 \%$ drift ratio, significant spalling in concrete occurred. Figure 9 (a) shows the hybrid models for Unit-4 beam-column joint specimen tested by Pantelides et al. [33]. The lateral force-displacement responses for measured and monotonically and cyclically computed using numerical simulation model are compared in Figure 9(b). The failure mode observed in the case study 
is captured with the diagonal concrete crushing. The peak strength in numerical model is 1.2 times the experimentally measured.

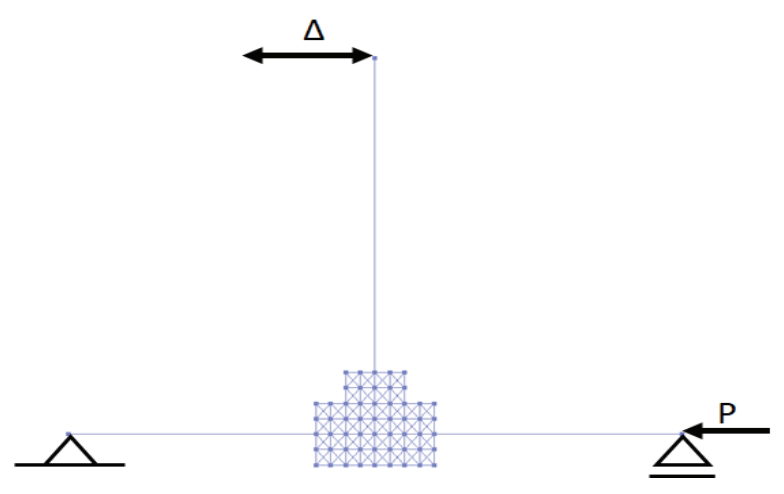

(a)

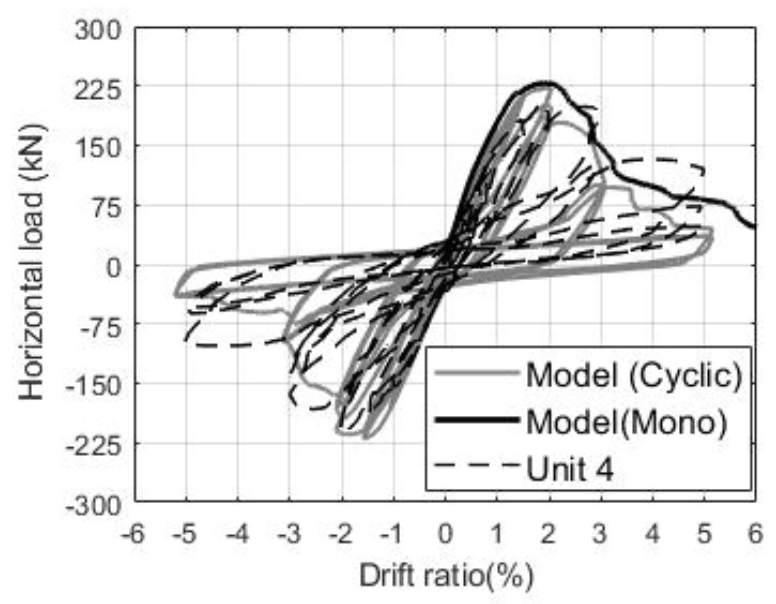

(b)

Figure 9 - (a) Numerical simulation model, and (b) Comparison of measured and computed responses for Unit 4 specimen (Pantelides et al., 2002) [33].

\section{ANALYSIS OF FRAME STRUCTURES}

Seismic performance of existing reinforced concrete buildings with unreinforced beamcolumn joints is investigated by analyzing hybrid models $(\mathrm{H})$ and a rigid model $(\mathrm{R})$ using incremental dynamic analysis (IDA) approach by Vamvatsikos and Cornell [34]. Incremental dynamic analysis approach (IDA) relates damage measures (inter-story drift ratios $\left(\theta_{\max }\right)$, rotations etc.) with corresponding intensity measures such as 5\% damped spectral acceleration at first-mode period $\left(\mathrm{Sa}\left(\mathrm{T}_{1}, 5 \%\right)\right)$. In this approach, one or more unscaled ground motion records (accelerograms) are selected and multiplied by a scale factor $\mathrm{S}_{\mathrm{a}}\left(\mathrm{T}_{1}\right.$, 
$5 \%$ ). Accelerograms are scaled so that $S_{a}$ is increased by $0.1 \mathrm{~g}$ and IDA curves are obtained by plotting $\left(\theta_{\max } ; \mathrm{S}_{\mathrm{a}}\left(\mathrm{T}_{1}, 5 \%\right)\right)$ pairs. In this study, incremental dynamic analyses (IDA) were performed by using Duzce (Turkey, 1999), Parkfield (USA, 1966) and Imperial Valley (USA, 1979) unscaled earthquake records shown in Figure 10 (PEER Strong Ground Motion Database, 2019) [35].
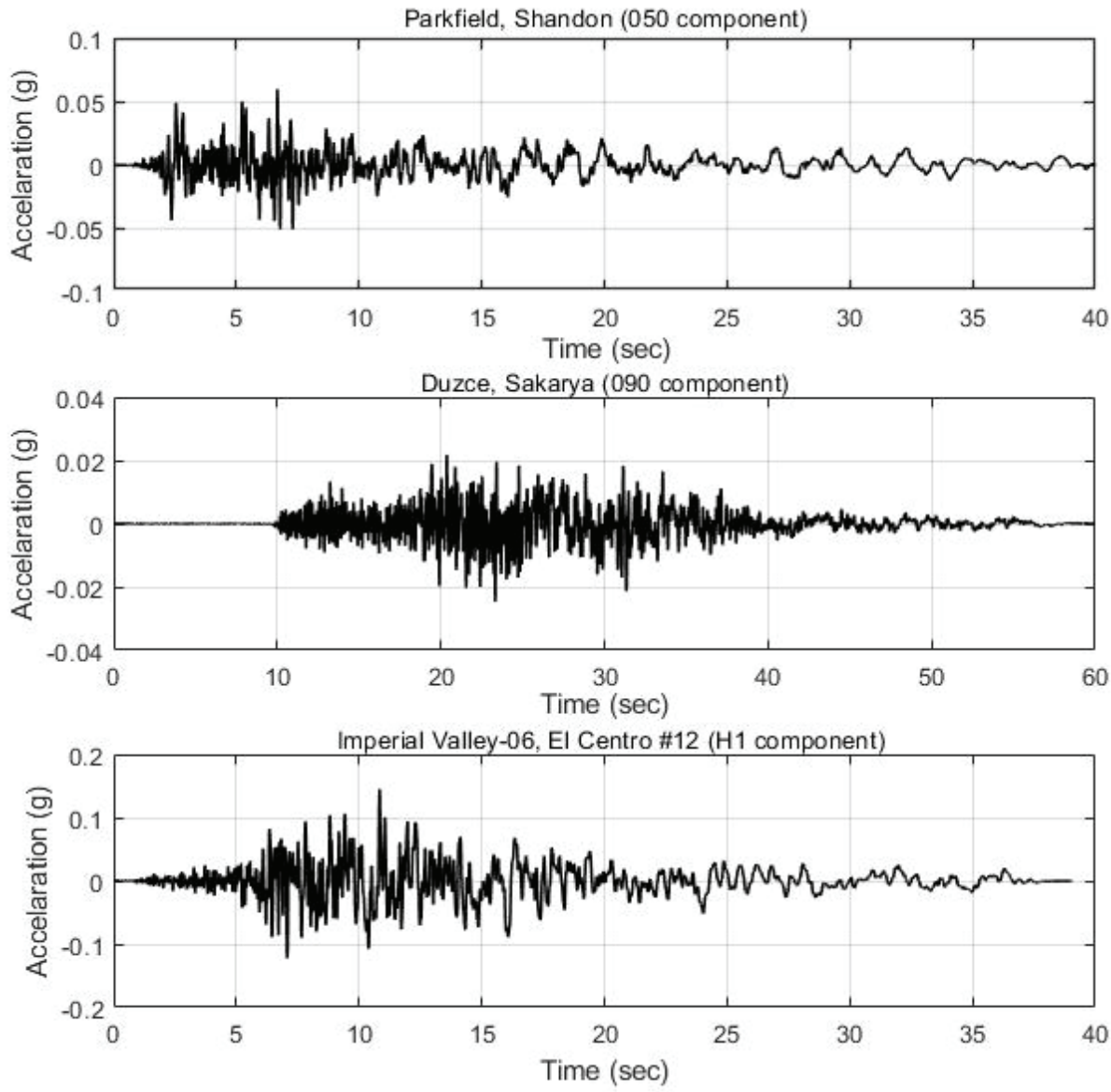

Figure 10 - Unscaled earthquake records for the incremental dynamic analyses [35]

Structural analysis models have similar longitudinal bar ratios and material strengths with S1 specimen and structural plan of the buildings as well as geometric details are shown in Figure 11. Calculated expected design loads based on tributary areas for a 4- story frame model is shown in Figure 12. Rayleigh damping corresponding to 5\% critical damping in the first and second modes is applied. Floor masses are assigned to the intersections of joint nodes and truss model and equal dof is assigned to the nodes at each story level. Four-story hybrid (H4) and six-story hybrid (H6) models have $1.16 \mathrm{sec}$ and $1.72 \mathrm{sec}$ fundamental periods (T1), respectively. 


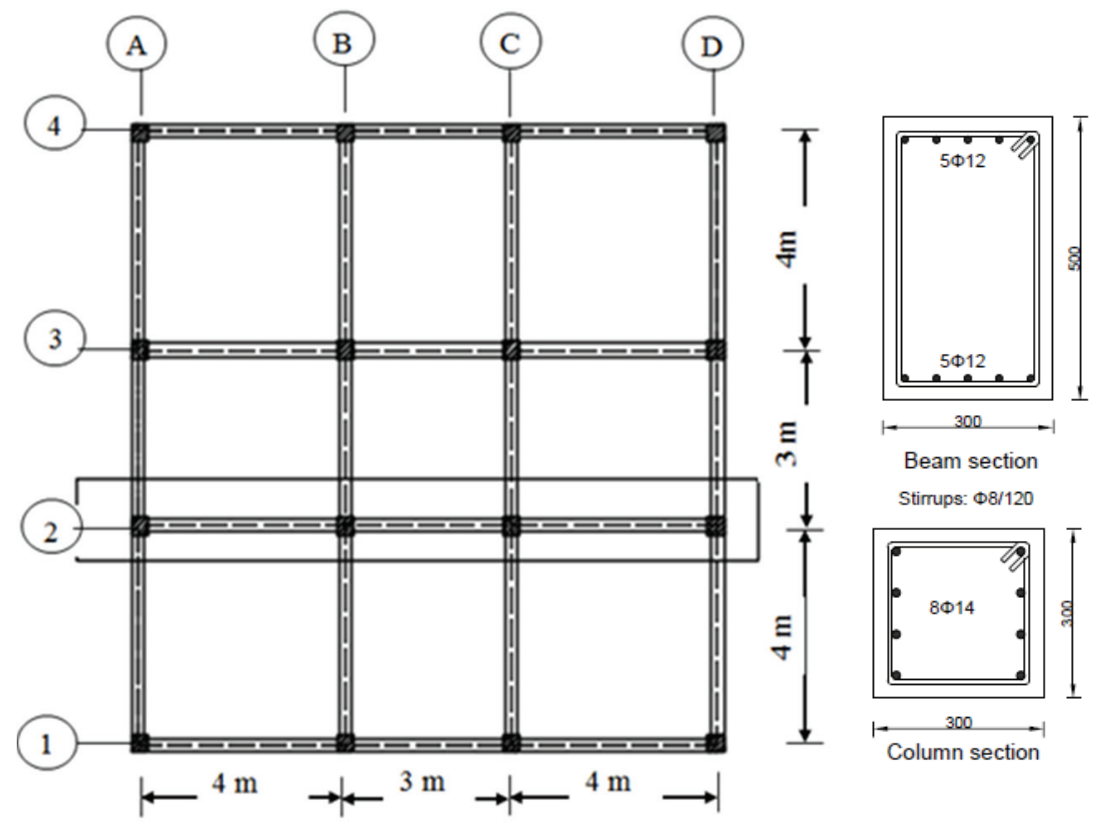

Figure 11 - Structural plan and column and beam reinforcing, and geometric details of RC building designed in 1970's

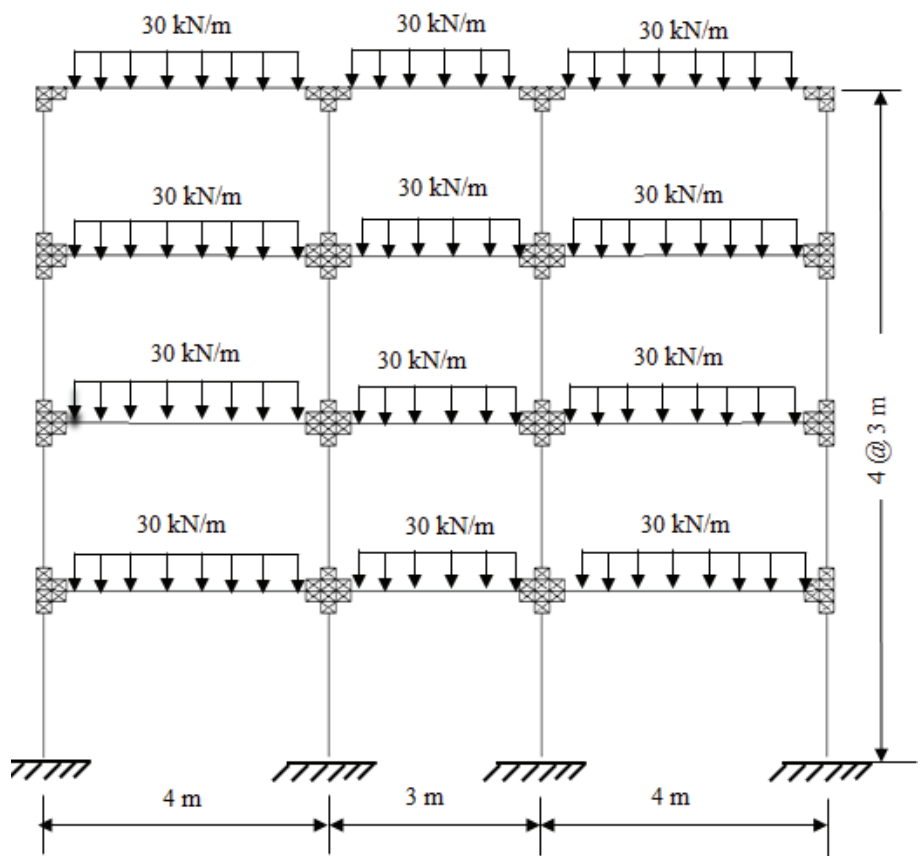

Figure 12 - Structural analysis model of four-story frame with hybrid connections (H4) 
IDA curves are obtained with respect to the nonlinear dynamic analysis results. IDA procedure is repeated based on FEMA 350 (2000) [36] until the slope between consecutive points on IDA curve is less than $0.2 \mathrm{~S}_{\mathrm{e}}$, where $\mathrm{S}_{\mathrm{e}}$ is the slope in elastic part. IDA curves in Figure 13 depict the relation between maximum inter-story drift ratios and spectral acceleration of the building for the amplitude scaled earthquake records. R4-P model with rigid joints reached a relatively lower drift ratio (2.5\%) than H4-P model $(4.2 \%)$ at same spectral acceleration $\left(\mathrm{Sa}\left(\mathrm{T}_{1}\right)=0.37 \mathrm{~g}\right)$. Figure 14 shows the roof displacement and corresponding base shear for structural models. Calculated maximum base shear for 4- and 6- story hybrid models are $106.5 \mathrm{kN}$ and $86.1 \mathrm{kN}$, respectively. However, 4-story model with rigid joint assumption (R4-P) computed the maximum base shear as $198 \mathrm{kN}$ which is approximately 2 times the base shear for hybrid models.

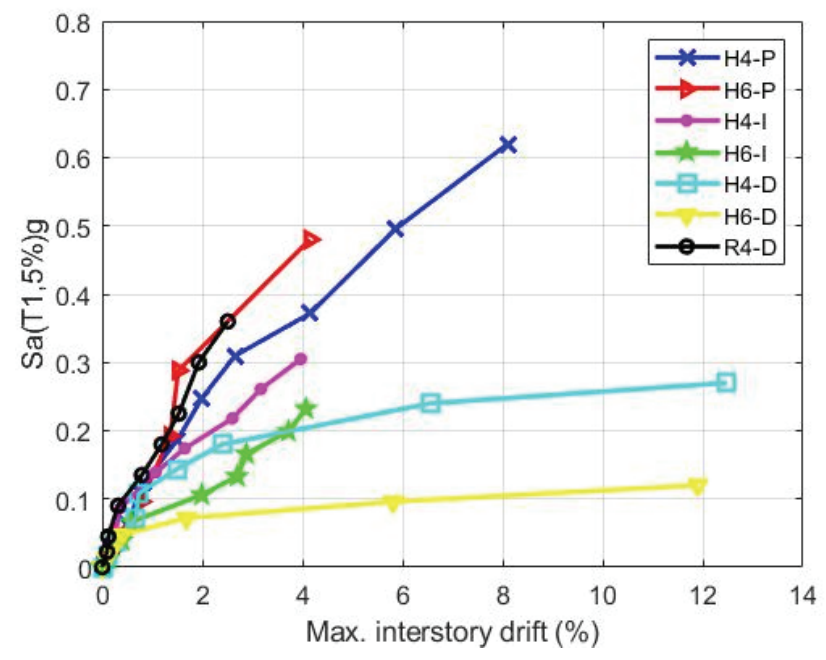

Figure 13 - IDA curves for 4- and 6 story structural models

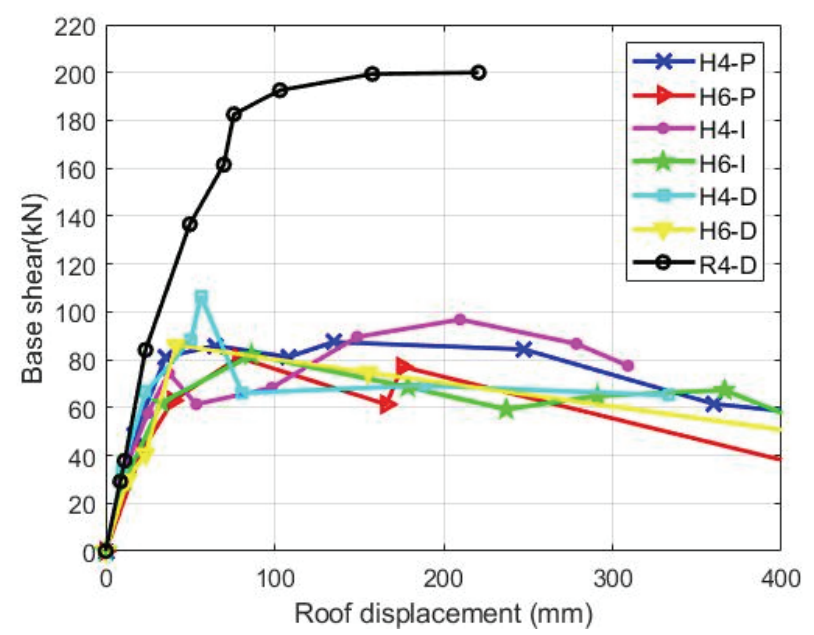

Figure 14 - Base shear-roof displacement relation for 4- and 6- story structural models 


\section{EVALUATION OF PERFORMANCE LIMITS}

Performance-based seismic design approach provides numerical estimation of damage in structural elements subjected to earthquake loading. Acceptable damage limits are stipulated to be compatible with the anticipated performance levels for different intensity levels of earthquakes by codes. Performance levels for a structural element are defined as immediate occupancy (IO), life safety (LS) and collapse prevention (CP) for rotation-based defined in ASCE/SEI 41 (2006) [37] or strain-based limit states in Turkish Building Earthquake Code (TBEC-2018) [38].

The generic normalized force-deformation ratio relation and the performance limit states corresponding to certain deformations for a ductile structural element are shown in Figure 15 [37]. In this figure, line $A B$ is the linear response up to effective yield point $B$ while line $B C$ represents the increase in strength due to strain hardening up to strength of the element $\mathrm{C}$. Significant strength degradation is represented by line $\mathrm{CD}$ and residual strength at point $\mathrm{E}$. The values in life safety (LS) performance level should be 0.75 times the deformation at point $\mathrm{C}$ which corresponds to collapse prevention (CP) performance level as given in [37].

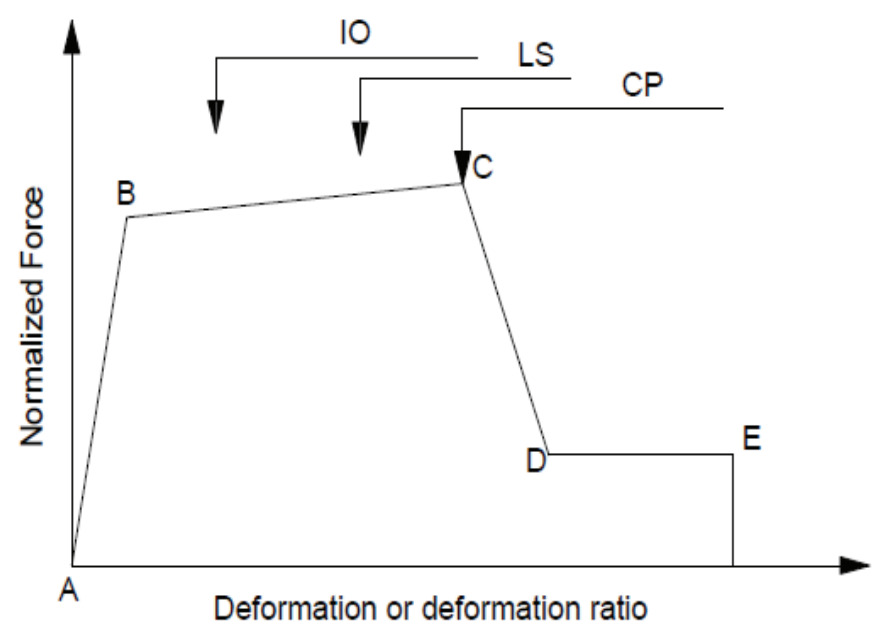

Figure 15 - Generalized component force-deformation relations [37]

Normalized moment- column rotation relationships of a ground story column for 4- and 6story hybrid and rigid structural models are shown in Figure 16. Plastic chord rotations for performance levels of columns are summarized in Table 1. Besides, column performance limit states corresponding to axial load ratios for 4- and 6- story models are defined by Table 6.8 in ASCE/SEI 41 [36] and include only plastic rotations as shown in Table 1. Models with hybrid connections predicted lower plastic rotations for RC columns than ASCE/SEI 41 (2006) provisions for IO and CP performance levels. Model with rigid joints have 2.5 times higher plastic rotation values for RC columns compared to ASCE/SEI 41 (2006) limits. In hybrid models, based on the strength degradation of beam-column joints with diagonal 
Effect of Modeling Beam-Column Joints on Performance Assessment of Columns ...

cracking, lateral loads of the structural system as well as column moment capacity are reduced.

Table 1 - Comparison of predicted RC column rotation-based limits for models and ASCE/SEI 41 [37] provisions

\begin{tabular}{|c|c|c|c|c|c|c|}
\hline \multirow{2}{*}{ Model } & \multicolumn{3}{|c|}{ Plastic rotations (rad) (Models) } & \multicolumn{3}{c|}{$\begin{array}{c}\text { Plastic rotations (rad) } \\
\text { (ASCE/SEI 41) }\end{array}$} \\
\cline { 2 - 7 } & $I O$ & $L S$ & $C P$ & $I O$ & $L S$ & $C P$ \\
\hline$H 4-P$ & 0.003 & 0.010 & 0.017 & 0.004 & 0.0135 & 0.017 \\
\hline$H 4-D$ & 0.003 & 0.009 & 0.015 & 0.004 & 0.0135 & 0.017 \\
\hline$R 4-P$ & 0.008 & 0.033 & 0.048 & 0.004 & 0.0135 & 0.017 \\
\hline$H 6-P$ & 0.003 & 0.008 & 0.013 & 0.003 & 0.012 & 0.015 \\
\hline$H 6-D$ & 0.0025 & 0.006 & 0.010 & 0.003 & 0.012 & 0.015 \\
\hline
\end{tabular}

*IO: immediate occupancy; LS: life safety; CP: collapse prevention performance level

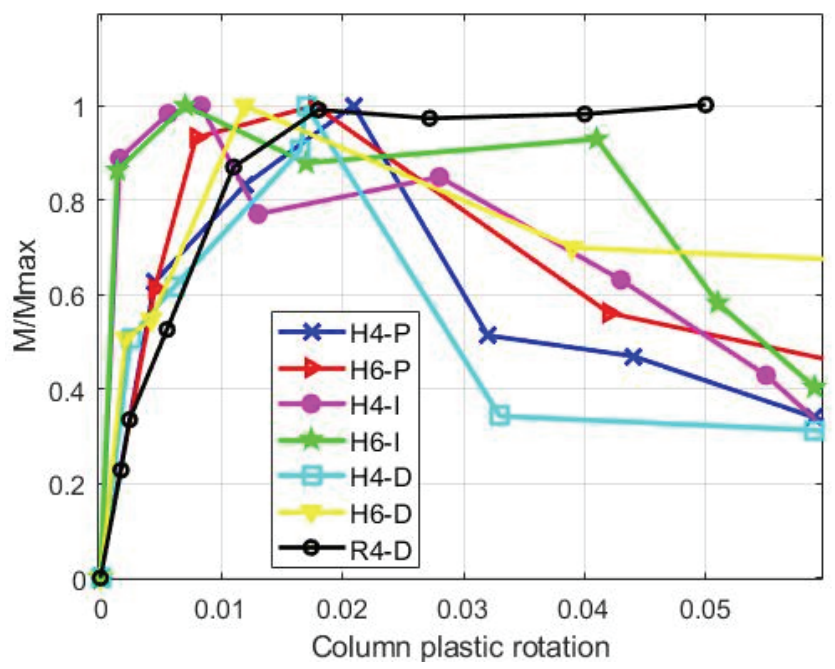

Figure 16 - Normalized moment-column chord rotations

Strain-based performance limits for seismic evaluation of reinforced concrete members are stipulated by Turkish Building Earthquake Code (TBEC-2018) [38]. Concrete and reinforcing bar strains for collapse prevention limit state are expressed by the equations below: 


$$
\varepsilon_{c}^{(C P)}=0.0035+0.07 \sqrt{\omega_{w e}} \leq 0.018
$$

and $\omega_{w e}=\alpha_{s e} \rho_{s h, \text { min }} \frac{f_{y w e}}{f_{c e}}$

where $\alpha_{s e}$ is the coefficient of effectiveness for transverse reinforcement, $\rho_{s h \text {, min }}$ is the minimum volumetric ratio of transverse reinforcing bar, $f_{y w e}$ and $f_{c e}$ are the expected yield strength of the transverse reinforcement and concrete, respectively.

$$
\begin{aligned}
& \alpha_{s e}=\left(1-\frac{\sum a_{i}^{2}}{6 b_{0} h_{0}}\right)\left(1-\frac{s}{2 b_{0}}\right)\left(1-\frac{s}{2 h_{0}}\right) \\
& \varepsilon_{s}^{(C P)}=0.4 \varepsilon_{s u}
\end{aligned}
$$

For life safety (LS) and immediate occupancy (IO) limit states concrete and reinforcing bar strains are defined as [38]:

$$
\begin{aligned}
& \varepsilon_{c}^{(L S)}=0.75 \varepsilon_{c}{ }^{(C P)} \text { and } \varepsilon_{s}{ }^{(L S)}=0.75 \varepsilon_{s}{ }^{(C P)} \\
& \varepsilon_{c}{ }^{(I O)}=0.0025 \text { and } \varepsilon_{s}{ }^{(I O)}=0.0075
\end{aligned}
$$

Strain-based performance limits for column shear force ratios greater than 1.3 should be decreased by $50 \%$ of the strain limits defined in TBEC (2018) [38]. The tabulated maximum strains in Table 2 for hybrid and rigid models are computed using the strain-column chord rotation plots shown in Figure 17 and were compared with the strain limits with the decreased limits in TBEC (2018) for columns at the ground story. Computed strains for models with rigid beam-column joint assumption (R4-P) have higher values than hybrid models.

Table 2 - Computed maximum strains in hybrid and rigid joint models for corresponding performance levels

\begin{tabular}{|c|c|c|c|c|c|c|c|c|}
\hline \multirow{2}{*}{$\begin{array}{c}\text { Performance } \\
\text { levels }\end{array}$} & Cover concrete & Core concrete & TBEC (2018) & Reinforcing bar & TBEC (2018) \\
\cline { 2 - 9 } & Hybrid & Rigid & Hybrid & Rigid & Concrete & Hybrid & Rigid & Reinforcing bar \\
\hline$I O$ & 0.0013 & 0.002 & 0.0011 & 0.0016 & 0.00125 & 0.0012 & 0.0022 & 0.0037 \\
\hline$L S$ & 0.0018 & 0.0049 & 0.0014 & 0.0048 & 0.00675 & 0.0015 & 0.0079 & 0.018 \\
\hline$C P$ & 0.0023 & 0.005 & 0.0019 & 0.007 & 0.009 & 0.0019 & 0.011 & 0.024 \\
\hline
\end{tabular}



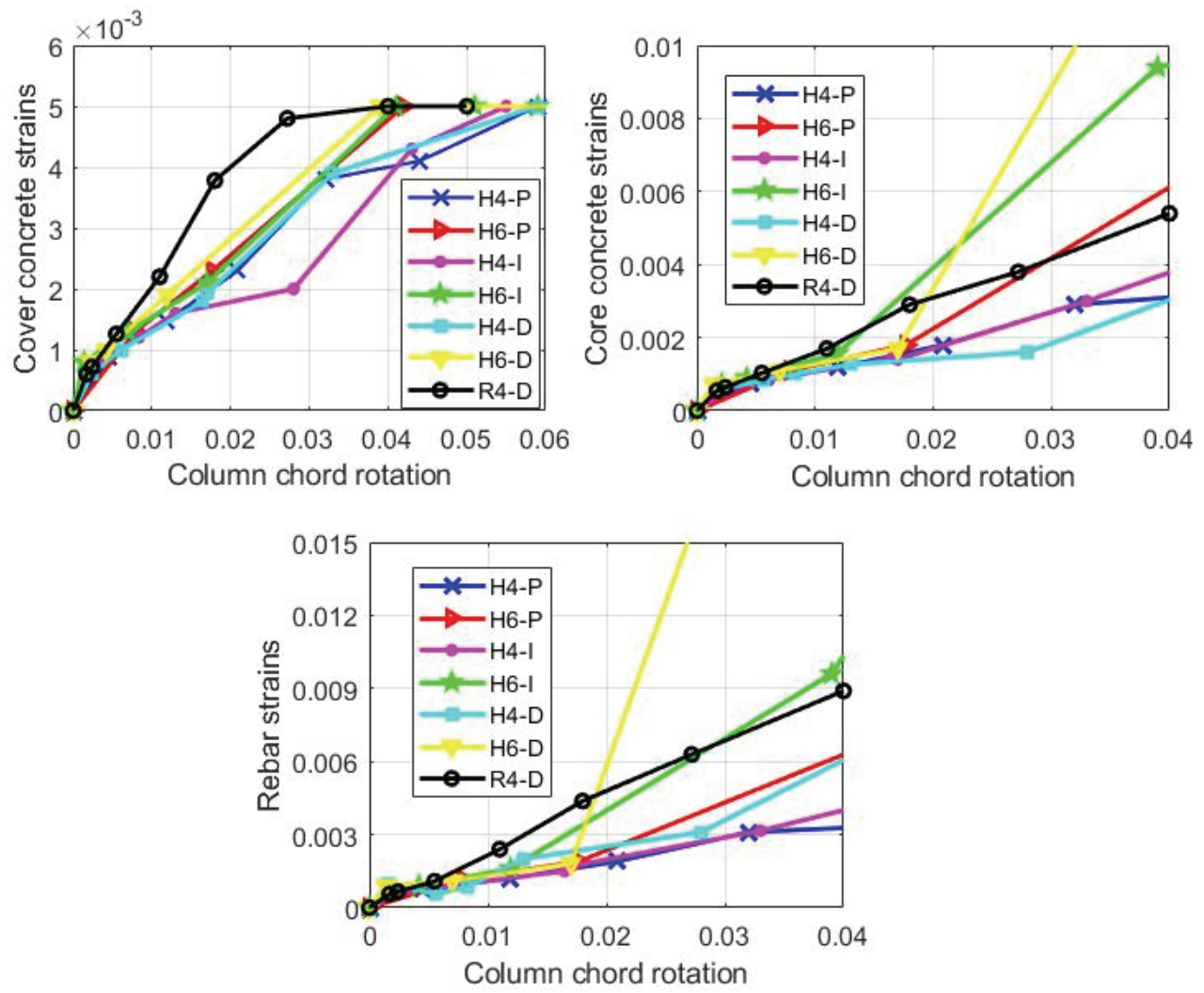

Figure 17 - Predicted column chord rotations and corresponding strains for (a) cover concrete, (b) core concrete and (c) reinforcing bars

\section{CONCLUSIONS}

This paper has presented a hybrid numerical model for performance-based seismic evaluation of columns of existing reinforced concrete buildings with non-seismically detailed beamcolumn joints. Hybrid numerical model including truss and fiber-based models has been validated with two exterior beam-column joint tests subjected to cyclic loading. Numerical model has simulated the observed joint behavior with crushing of diagonal elements at the joints. Developed four and six story frame models have been analyzed by performing nonlinear incremental dynamic analyses. Rotation-based performance limit states for RC columns of non-ductile frames have been investigated and compared with ASCE/SEI 41 (2006) provisions. Besides, strain-based limits have been obtained for cover concrete, core concrete and reinforcing bar strains of reinforced concrete columns at the ground story and compared with TBEC (2018) provisions. The results showed that plastic rotations and corresponding concrete and reinforcing bar strains of columns have relatively lower values than the code provisions for life safety (LS) and collapse prevention (CP) performance limits. Modeling non-ductile RC frames with rigid joint assumption has led to an underestimation 
in damage levels of members. Further numerical studies should be performed considering bond slip of beam reinforcing bars in interior joints and reinforcing material models accounting for buckling and rupture. Also, performance limit states for beams and joints should be performed by increasing the number of ground motion records in the scope of future studies.

\section{Symbols}

$\boldsymbol{a}_{i}=$ distance between axes of longitudinal bars which are supported with a tie leg [mm]

$\boldsymbol{b}_{\boldsymbol{0}}=$ cross-section dimension between axes of ties confining the core area $[\mathrm{mm}]$

$\boldsymbol{B}_{s}=$ post-yield hardening ratio

$\boldsymbol{d}_{\boldsymbol{b}}=$ longitudinal bar diameter $[\mathrm{mm}]$

$\boldsymbol{E}_{\boldsymbol{s}}=$ Young Modulus of reinforcing steel material [MPa]

$\boldsymbol{f}_{\boldsymbol{c}}$ ' $=$ Compressive strength of unconfined concrete [MPa]

$f_{c e}=$ Average (expected) compressive strength of concrete [MPa]

$f_{c k}=$ Characteristic compressive strength of unconfined concrete [MPa]

$\boldsymbol{f}_{\boldsymbol{t}}=$ Tensile strength of concrete [MPa]

$\boldsymbol{f}_{\boldsymbol{y}}=$ Yield strength of longitudinal bar [MPa]

$\boldsymbol{f}_{\boldsymbol{y} w \boldsymbol{e}}=$ Average (expected) yield strength of transverse bar [MPa]

$\boldsymbol{h}_{\boldsymbol{0}}=$ cross-section dimension between axes of ties confining the core area [mm]

$\boldsymbol{M}=$ tension stiffening parameter

$s=$ tie spacing $[\mathrm{mm}]$

$S_{a}\left(T_{1}\right)=$ spectral acceleration at first-mode period $\left[\mathrm{m} / \mathrm{sn}^{2}\right]$

$\boldsymbol{T}_{1}=$ period corresponding the fundamental mode (sn)

$\boldsymbol{\alpha}_{s e}=$ coefficient of effectiveness for transverse reinforcement

$\boldsymbol{\beta}=$ reduction coefficient

$\varepsilon_{0}=$ Compressive strain of unconfined concrete at maximum strength

$\varepsilon_{c}{ }^{(C P)}=$ Compressive strain limit of concrete at collapse prevention limit state

$\varepsilon_{s}{ }^{(C P)}=$ Strain limit of reinforcing bar at collapse prevention limit state

$\varepsilon_{n}=$ normal strains in concrete

$\varepsilon_{u}=$ Ultimate compressive strain of unconfined concrete at maximum strength

$\varepsilon_{y}=$ Yield strain of longitudinal bar

$\boldsymbol{\theta}_{\max }=$ maximum inter-story drift ratios 
$\boldsymbol{\rho}_{\mathrm{sh}, \boldsymbol{m i n}}=$ minimum volumetric ratio of transverse reinforcing bar

$\rho_{\boldsymbol{l}}=$ longitudinal reinforcing bar ratio

$\omega_{c e}=$ mechanical reinforcing bar ratio of effective confinement

\section{Acknowledgement}

The author would like to thank Prof. Dr. Serap Kahraman and Assoc. Prof. Dr. Ibrahim Serkan Misir for sharing the beam-column test data and providing their valuable opinions during preparation of the study.

\section{References}

[1] Hanson, N. W., \& Conner, H. W. 1967, Seismic resistance of reinforced concrete beamcolumn joints, J. of Str. Div., 93(5), 533-560, 1967.

[2] Park, R., and Paulay, T., Behaviour of reinforced concrete external beam-column joints under cyclic loading, Proceedings of the 5th World Conference on Earthquake Engineering, Rome, 1973.

[3] Kunnath, S. K., Hoffmann, G., Reinhorn, A. M., Mander, J. B., Gravity-load-designed reinforced concrete buildings - Part I: Seismic evaluation of existing construction, ACI Structural Journal, 92(3), 343-354, 1995.

[4] Hakuto, S., Park, R., Tanaka, H., Seismic load tests on interior and exterior beam column joints with substandard reinforcing details, ACI Structural Journal, 97(1), 1125,2000 .

[5] Park, R., A summary of results of simulated seismic load tests on reinforced concrete beam-column joints, beams and columns with substandard reinforcing details, J. of Earth. Eng., 6(2), 147-174, 2002.

[6] Bedirhanoglu, I., Ilki, A., Pujol, S. and Kumbasar, N., Behavior of deficient joints with plain bars and low-strength concrete, ACI Structural Journal, 107(3), 300-310, 2010.

[7] Gökdemir, H. and Tankut, T., Kiriş-kolon birleşim bölgesinin depreme karş1 çelik donatılarla güçlendirilmesi, İMO Teknik Dergi, 7977-7992, 2017.

[8] Moehle, Jack P. Seismic design of reinforced concrete buildings. New York: McGrawHill Education, 2015.

[9] Alire, D., Seismic evaluation of existing unconfined reinforced concrete beam-column joints, M.S. Thesis, University of Washington, Seattle, WA, 306pp, 2002.

[10] Lima C., Martinelli, E., Macorini, L. and Izzuddin, B. A., Modelling beam-to-column joints in seismic analysis of RC frames, Earthquakes and Structures, 12(1), 119-133, 2017. 
[11] Bayhan, B., Özdemir, G., and Gülkan, P., Impact of joint modeling approach on performance estimates of older-type RC buildings, Earthquake Spectra, 33(3), 11011123, 2017.

[12] Calvi, G. M., Magenes, G., and Pampanin, S., Relevance of beam-column joint damage and collapse in RC frame assessment, J. of Earth. Eng., 6(1), 75-100, 2002.

[13] Favvata, M. J., Izzuddin, B. A., and Karayannis, C. G., Modelling exterior beamcolumn joints for seismic analysis of RC frame structures, Earth. Eng. and Str. Dyn. 37(13), 1527-1548, 2008.

[14] Sharma, A., Eligehausen, R., and Reddy, G. R., Pivot hysteresis model parameters for reinforced concrete columns, joints, and structures, ACI Structural Journal, 110(2), 217-227, 2013.

[15] Bedirhanoğlu, I, Düşük dayanımlı betona sahip betonarme kolon ve birleşimlerin deprem yükleri altında davranışlarının incelenmesi ve iyileştirilmesi, Doktora tezi, İstanbul Teknik Üniversitesi Fen Bilimleri Enstitüsü, 2009.

[16] Youssef, M., and Ghobarah, A., Modelling of RC beam-column joints and structural walls, Jour. of Earth. Eng., 5(1), 93-111, 2001.

[17] Lowes, L. N., Mitra, N., and Altoontash, A., A beam-column joint model for simulating the earthquake response of reinforced concrete frames, Report No. PEER 2003/10; Pacific Earthquake Engineering Research Center, College of Engineering, University of California, Berkeley, 2003.

[18] Park, S. and Mosalam, K.M., Simulation of reinforced concrete frames with nonductile beam-column joints. Earthquake Spectra, 29(1), 233-257, 2013.

[19] Kostic, S., and Filippou, F., Section discretization of fiber beam-column elements for cyclic inelastic response. Jour. of Str. Eng., 138, 592-601, 2012.

[20] Kim, J. H., and Mander, J. B. Truss modeling of reinforced concrete shear - flexure behaviour, MCEER Report 99-0005, University at Buffalo, State University of New York, 1999.

[21] Miki, T., and Niwa, J., Nonlinear analysis of RC structural members using 3D lattice model, J. of Adv. Con. Tech., 2(3), 343-358, 2004.

[22] Park, H., and Eom, T., Truss model for nonlinear analysis of RC members subject to cyclic loading, J. of Str. Eng., 133(10), 1351-1363, 2007.

[23] To, N., Sritharan, S., and Ingham, J., Strut-and-tie nonlinear cyclic analysis of concrete frames", J. of Str. Eng., 135(10), 1259-1268, 2009.

[24] Panagiotou, M., Restrepo, J. I., Schoettler, M., and Kim, G., Nonlinear cyclic truss model for reinforced concrete walls, ACI Structural Journal, 109(2), 205-214, 2012.

[25] Moharrami M., Koutromanos I., Panagiotou M., Girgin S.C., Analysis of sheardominated RC columns using the nonlinear truss analogy, Earth. Eng. and Str. Dyn., 44(5), 677-694. 
[26] Bowers, J.T., Nonlinear cyclic truss model for beam-column joints of non-ductile RC frames. M.Sc. thesis, Virginia Polytechnic and State University, 2014.

[27] Xing C., Koutromanos I., Leon R., and Moharrami M., Computational simulation of RC Beam-to-Column Connections Under Earthquake Loading, Eleventh US National Conference on Earthquake Engineering, Loa Angeles, CA, USA, 2018.

[28] McKenna, F., Fenves, G. L., Scott, M. H., and Jeremic, B. Open system for earthquake engineering simulation. http://opensees.berkeley.edu, 2015.

[29] Lu, Y. and Panagiotou, M., Three-dimensional cyclic beam-truss model for non-planar reinforced concrete walls, J. of Str. Eng., 140(3), 2014.

[30] Stevens, N. J., Uzumeri, S. M., Collins, M. P., and Will, T. G., Constitutive model for reinforced concrete finite element analysis, ACI Structural Journal, 99(10), 2109-2122, 1991.

[31] Vecchio, F. G. \& Collins, M.P., The modified compression field theory for reinforced concrete elements subjected to shear, J. of the American Con. Inst., 83(2), 219-231, 1986.

[32] Misir, I. S., \& Kahraman, S., Strengthening of non-seismically detailed reinforced concrete beam-column joints using SIFCON blocks, Sadhana, 38(1), 69-88, 2013.

[33] Pantelides, C.P., Hansen, J., Nadauld, J. and Reaveley, L.D., Assessment of reinforced concrete building exterior joints with substandard details. PEER report, 2002.

[34] Vamvatsikos, Dimitrios, \& Cornell, C.A., Incremental dynamic analysis. Earth. Eng. \& Str. Dyn. 31.3:491-514, 2002.

[35] Pacific Earthquake Engineering Research (PEER) Center, PEER Strong MotionDatabase, https://peer.berkeley.edu/peer-strong-ground-motion-databases/, 2019.

[36] FEMA 350 (2000). Recommended seismic design criteria for new steel moment-frame buildings. Federal Emergency Management Agency, 2000.

[37] ASCE/SEI 41, Seismic rehabilitation of existing buildings, Reston, VA, U.S.A 2006.

[38] Turkish Building Earthquake Code (TBEC), Principles for the design of buildings under earthquake, Ankara, Turkey, 2018. 